\section{Evaluation of Organic Amendments and Flaming for Weed Control in Matted-row Strawberry}

\author{
Timothy W. Miller ${ }^{1}$ and Carl R. Libbey \\ Washington State University, 16650 State Route 536, Mount Vernon, WA \\ 98273
}

\author{
Brian G. Maupin \\ Homer Soil and Water Conservation District, 4014 Lake Street, Suite 201A, \\ Homer, AK 99603
}

Additional index words. corn gluten meal, Fragaria $\times$ ananassa, mustard seed meal, wheat gluten

\begin{abstract}
Propane flaming and organic amendments were evaluated for usefulness in matted-row strawberry (Fragaria Xananassa Duch.). Flaming was used once before transplanting 'Hood' strawberry (PRETR), twice before transplanting (PRETR + PRETR), or once before and once after transplanting (PRETR + POSTR) and compared with rototilling before transplanting in 2000-02. Organic amendments tested across flame treatments included corn gluten meal (CGM) at two rates, wheat gluten (WG), and mustard seed meal (MSM) with high or low glucosinolate content, and herbicides included oxyfluorfen, pendimethalin, and a combination of oxyfluorfen + pendimethalin. Amendments/herbicides were applied immediately POSTR in Year 1 and again to established plants in late winter of Year 2. All plots were weeded by hand after weed evaluations were completed and weeding hours recorded. The trial was conducted twice: Iteration 1 and Iteration 2. Effect of flaming on grass and broadleaf weed ratings was brief during Year 1 of both iterations, with only slight differences observed in June and no differences by September. Total weeding time was reduced $12 \%$ by flaming PRETR once compared with rototilling in Iteration 1 and was reduced $10 \%$ by all flame treatments in Iteration 2. Rototilling reduced total berry yield and average individual fruit weight compared with flaming treatments in Iteration 1; there was no significant effect of flame on strawberry yield or individual fruit weight in Iteration 2. Organic amendments did not reduce weeding time in Iteration 1 compared with the nontreated control, although weeding time was increased $18 \%$ by CGM at $487 \mathrm{~kg} \cdot \mathrm{ha}^{-1}$ compared with synthetic herbicide treatments. In Iteration 2 , total weeding time was reduced $14 \%$ for the two pendimethalin treatments and for high-glucosinolate MSM compared with nontreated control plots. First-year strawberry leaf area was reduced by oxyfluorfen + pendimethalin compared with nontreated strawberries $\left(802\right.$ and $1086 \mathrm{~cm}^{2} / \mathrm{plant}$, respectively) and was generally increased with organic amendments. Strawberry yield in Iteration 1 was increased $\approx 14 \%$ by CGM at $974 \mathrm{~kg} \cdot \mathrm{ha}^{-1}$ and WG and low-glucosinolate MSM compared with nontreated strawberry. Oxyfluorfen and oxyfluorfen + pendimethalin reduced strawberry yield by $\approx \mathbf{2 0} \%$ and average individual fruit weight by $\approx 9 \%$ (14.8 and $14.5 \mathrm{~g} /$ fruit) compared with nontreated strawberry (16.1 g/fruit); highglucosinolate MSM also reduced average individual fruit weight to $14.8 \mathrm{~g} / \mathrm{fruit}$. There were no significant effects of amendments/herbicides on strawberry yield parameters in Iteration 2.
\end{abstract}

Weed control in matted-row strawberry culture systems of the Pacific Northwest (PNW) is a difficult challenge. Like in most of the northern United States, PNW strawberries

Received for publication 14 Aug. 2012. Accepted for publication $11 \mathrm{Jan} .2013$.

Funding for these trials was received from the Washington State Commission on Pesticide Registration and the Washington State Strawberry Commission.

Use of trade names does not imply an endorsement of the products named or criticism of similar ones not named.

${ }^{1}$ To whom reprint requests should be addressed; e-mail twmiller@wsu.edu. disturb rooting of daughter plants within the row as weeds are removed, potentially delaying row closure and strawberry establishment. Plastic mulches are widely used for weed control in annual strawberry production (Berglund et al., 2006; Johnson and Fennimore, 2005), but they prevent daughter plant establishment and therefore are not suitable for matted-row systems (Kelly et al., 2007). In effort to improve in-row weed control in organic matted-row strawberry, natural weed control products and practices have been evaluated.

Corn gluten meal has shown promise as an organic amendment. It contains $\approx 10 \%$ nitrogen $(\approx 47 \%$ crude protein) and has been used as both a fertilizer and weed control product (Christians, 1993). In strawberry, $90 \%$ reduction in cover of common lambsquarters (Chenopodium album), common purslane (Portulaca oleracea), redroot pigweed (Amaranthus retroflexus), large crabgrass (Digitaria sanguinalis), and green, giant, and yellow foxtail (Setaria viridis, $S$. faberi, and S. pumila, respectively) was reported from application of $490 \mathrm{~g} \cdot \mathrm{m}^{-2}$ (Nonnecke and Christians, 1997). Applied at renovation in July, CGM increased weed cover and weed density by August, but if applied in August, CGM reduced weed cover and dicot weed density by September (Nonnecke and Christians, 2002). Conversely, CGM applied in July reduced dicot weeds by August in two of three years, although strawberry yield increased in only one year (Dilley et al., 2002). Strawberry yield was also decreased if CGM was applied too often in a single growing season, likely as a result of excess nitrogen contributing to abundant foliar growth (Nonnecke and Christians, 1997). In Turkey, CGM at $4 \mathrm{t} \cdot \mathrm{ha}^{-1}$ applied in August before transplanting of strawberry resulted in control of shepherd'spurse (Capsella bursa-pastoris), annual bluegrass (Poa annua), and prostrate knotweed (Polygonum aviculare) $(80 \%, 74 \%$, and $49 \%$, respectively) by May (Albay and Boz, 2003). Like CGM, WG inhibited weed seedling growth (Gough and Carlstrom, 1999), but there are no reports for use of WG in strawberry.

Mustard seed meal contains glucosinolates, which break down in soil to isothiocyanate in moist soil (Borek and Morra, 2005; Brown et al., 1991; Vaughn and Berhow, 2005; Vaughn et al., 2006). Boydston et al. (2011) demonstrated that much of the herbicidal activity of MSM is the result of its glucosinolate content with effective doses for $90 \%$ redroot pigwweed control of 14.5 and $3.2 \mathrm{~g} \cdot \mathrm{m}^{-2}$ for two high-glucosinolate MSM, although low-glucosinolate MSM has also suppressed growth of common purslane and redroot pigweed (Bañuelos and Hanson, 2010). High-glucosinolate MSM (yellow mustard, Sinapis alba) provided up to $98 \%$ control of annual bluegrass, 74\% control of common chickweed (Stellaria media), $95 \%$ of creeping woodsorrel (Oxalis corniculata), and 97\% control of liverwort (Marchantia polymorpha) with no observable injury to containergrown ornamentals (Boydston et al., 2008). 
High-glucosinolate MSM ( $S$. alba) applied up to $4.5 \mathrm{t} \cdot \mathrm{ha}^{-1}$ reduced counts of common lambsquarters, redroot pigweed, and henbit (Lamium amplexicaule) by up to $50 \%$ but also reduced onion bulb yield $29 \%$ when applied three times at $2.2 \mathrm{t} \cdot \mathrm{ha}^{-1}$ (Boydston et al., 2011). Rice et al. (2007) reported 72\% to $99 \%$ control of common lambsquarters and redroot pigweed with high-glucosinolate $\operatorname{MSM}($ S. alba) but also $80 \%$ injury to seeded vegetables in one year out of two. The pesticidal effects of Brassicaceous seed meals on insects and soilborne pathogens has been reported, but effects have been variable (Borek et al., 1997; Mazzola et al., 2001; Smolinska et al., 1997). High-glucosinolate MSM (brown mustard, Brassica juncea) has been shown to be toxic to dagger nematode (Pratylenchus penetrans) at rates of $0.05 \%$ to $0.1 \%(\mathrm{w} / \mathrm{w})$ in soil with no reduction in strawberry shoot or root dry weight (Qing et al., 2007).

Flame has been used for selective weed control in crop production since the early 1940s (Anderson, 1977). Flame weeding is most commonly used as part of a stale seedbed strategy; crops are seeded several days after final seedbed preparation and weeds removed with flame before crop emergence. Organic vegetable growers have used flaming coupled with a stale seedbed for many years (Cramer et al., 1991; Stopes and Millington, 1991; Wookey, 1985). These techniques reduced density and biomass of common purslane and common chickweed in simulated vegetable seedings (Caldwell and Mohler, 2001). A single flaming $4 \mathrm{~d}$ after seedbed preparation and $1 \mathrm{~d}$ before transplanting lettuce seedlings reduced weed density by $62 \%$ (Balsari et al., 1994). Although propane flame applied at summer renovation is sometimes used to reduce disease inoculum and mite infestations in strawberry (Daugaard, 1999; Meshcheryakova, 1986; Titov, 1986), flaming for weed control in this crop has not been widely investigated. The usefulness of flame for weed control in newly planted strawberry has been noted, but only as a factor in reducing a reservoir for other plant pests (Gengotti and Lucchi, 2000).

Corn and wheat gluten products, MSM products, and propane flaming may offer additional weed control options for both organic and conventional strawberry producers in the PNW. Because neither crop safety of these treatments nor their efficacy on the weed species that flourish in the maritime climate of western Washington state had been previously documented, a trial was conducted to evaluate efficacy and crop safety of organic amendments and propane flaming in matted-row strawberry.

\section{Materials and Methods}

The trial was conducted at Washington State University Northwestern Washington Research and Extension Center $\approx 3 \mathrm{~km}$ west of Mount Vernon, WA, in 2000-01 (Iteration 1) and repeated in 2001-02 (Iteration 2). Soil type for both iterations was a Skagit silt loam (Fine-silty, mixed, nonacid, mesic Typic
Fluvaquents). Rows measuring $27 \mathrm{~m}$ long were flagged at a spacing of $105 \mathrm{~cm}$ on a freshly tilled soil in spring. Weed seed resident in the plots germinated and weeds were allowed to grow for $14 \mathrm{~d}$, after which three adjacent rows were marked to receive one of three flaming treatments: 1) flamed once at $14 \mathrm{~d}$ after tillage and a second time immediately before strawberry transplanting, $\approx 10 \mathrm{~d}$ later (PRETR + PRETR); 2) flamed once at $14 \mathrm{~d}$ after tillage and a second time immediately after strawberry transplanting, $\approx 10 \mathrm{~d}$ later (PRETR + POSTR); or 3) flamed once immediately before strawberry transplanting, $\approx 24 \mathrm{~d}$ after tillage (PRETR). A handheld open propane burner was used to flame all plots; an average of $4.2 \mathrm{~kg}$ of propane was burned in each iteration, equivalent to a rate of $\approx 86 \mathrm{~kg} \cdot \mathrm{ha}^{-1}$ broadcast rate (25 kg.ha ${ }^{-1}$, banded rate). Three additional adjacent rows were not flamed, but instead were rototilled once immediately before strawberry transplanting to represent standard industry practice. Early PRETR flaming was done 3 June 2000 and 18 May 2001 for Iterations 1 and 2, respectively, late flaming (both PRETR and POSTR) on 13 June 2000 and 29 to 30 May 2001, and rototilling on 13 June 2000 and 29 May 2001

Dormant, bare-root 'Hood' strawberry plants (Sakuma Brothers Farms, Bow, WA) were transplanted by hand 13 June 2000 and 29 May 2001 using 45-cm spacing between plants. Rows were divided into nine 3-m plots corresponding to nine weed control treatments placed perpendicularly to flame treatments. Resultant subplot size was $3 \mathrm{~m}$ long $X$ $3.15 \mathrm{~m}$ wide and included three strawberry rows. Organic amendments included CGM (Walt's Organic Weed-Stopper Plus; Walt's Organic Fertilizer Company, Inc., Seattle, WA), wheat gluten (Bob's Red Mill Wheat Gluten; Natural Foods, Inc., Milwaukie, OR), and high- and low-glucosinolate MSM (Sinapis alba L., 'IdaGold' and UI 7012G, respectively, obtained from Dr. Jack Brown, Department of Plant, Soil, and Entomological Sciences, University of Idaho, Moscow, ID). High-glucosinolate MSM contained sinalbin (4-hydroxybenzyl glucosinolate) and progoitrin (2-hydroxy-3-butenyl glucosinolate) at 173 and $7 \mu$ mole. $g^{-1}$ of defatted meal, respectively; low-glucosinolate MSM contained less than $2 \mu$ mole glucosinolate/gram. Amendments were applied in a $30-\mathrm{cm}$ band centered on each strawberry row and were rainfall-incorporated. Application rates for CGM was 487 and $974 \mathrm{~kg} \cdot \mathrm{ha}^{-1}$, WG at $700 \mathrm{~kg} \cdot \mathrm{ha}^{-1}$, and high- and low-glucosinolate MSM at $644 \mathrm{~kg} \cdot \mathrm{ha}^{-1}$; banded rate equivalents in the strawberry row were $\approx 1680$ and $3360 \mathrm{~kg} \cdot \mathrm{ha}^{-1}$ for CGM, $2464 \mathrm{~kg} \cdot \mathrm{ha}^{-1}$ for $\mathrm{WG}$, and $2240 \mathrm{~kg} \cdot \mathrm{ha}^{-1}$ for both types of MSM. A total of $9 \mathrm{~mm}$ of rainfall occurred in the first $3 \mathrm{~d}$ after application in $2000(16 \mathrm{~mm}$ in the first $30 \mathrm{~d}$ ) and $32 \mathrm{~mm}$ in the first $4 \mathrm{~d}$ after application in 2001 (114 $\mathrm{mm}$ in the first $30 \mathrm{~d})$. Monthly precipitation totals for the duration of the experiment are provided in Table 1. Separate treatments of oxyfluorfen (Goal 2XL; Dow AgroSciences, Indianapolis,
IN), pendimethalin (Prowl 3.3EC; BASF Corporation, Research Triangle Park, NC), and oxyfluorfen + pendimethalin applied POSTR, broadcast, were included for comparison (active ingredient rates of $0.43 \mathrm{~kg} \cdot \mathrm{ha}^{-1}$, $2.24 \mathrm{~kg} \cdot \mathrm{ha}^{-1}$, and $0.28+1.12 \mathrm{~kg} \cdot \mathrm{ha}^{-1}$, respectively). Herbicides were applied using a $\mathrm{CO}_{2}$-pressurized backpack sprayer delivering $282 \mathrm{~L} \cdot \mathrm{ha}^{-1}$ at $255 \mathrm{kPa}$. All amendments/ herbicides were applied twice: the first immediately post-transplant of Year 1 (13 June 2000 and 30 May 2001) and the second early in Year 2 (23 Mar. 2001 and 1 Feb. 2002). Because organic amendments contained nitrogen $(\mathrm{N})$ that would become available for strawberry or weed growth (CGM and $\mathrm{WG}=$ $10 \%$ total $\mathrm{N}, \mathrm{MSM}=6 \%$ total $\mathrm{N}$ ), ammonium nitrate was applied to bring the total applied $\mathrm{N}$ for all plots (including the plots treated with conventional herbicides and the nontreated control plots) to the same total $\mathrm{N}$ level as was applied with the high rate of CGM $\left(97.4 \mathrm{~kg} \cdot \mathrm{ha}^{-1}\right)$. Ammonium nitrate was applied to the soil surface in a band over the row at the same time as the organic amendments. No other fertilizers were applied and plots were not irrigated in either iteration.

All plots were weeded by hand six times after strawberry transplanting (June, July, August, and September of Year 1 and March and April of Year 2) and the time required for those weedings was recorded. Before handweeding, weed density level (scale from 0 to 5; $0=$ no weeds, $5=$ high weed density) was visually evaluated 27 June and 14 Sept. 2000 for Iteration 1 and 15 June and 10 Sept. 2001 for Iteration 2. Between-row sections of all plots were rototilled in October of Year 1 of both iterations; strawberry runners rooting between rows were physically moved into the row before tillage. One strawberry plant from each row in every split plot (a total of three plants per treatment) was pulled from the soil 5 to 7 Sept. 2000 and 14 to 15 Aug. 2001 and leaves, runners, and daughter plants were counted and leaf area measured (LI 3100 Leaf Area Meter; LI-COR, Inc., Lincoln, $\mathrm{NE}$ ). Ripe berries were picked three times in early summer of Year 2 (21 June, 28 June, and 2 July 2001 and 24 June, 1 July, and 10 July 2002). Fruit were sorted to remove diseased or otherwise unmarketable berries and the remaining fruit were counted and weighed.

The experimental design was a strip-plot design with four replicates. Propane flaming or rototilling was applied within rows and organic amendment or herbicides were applied across rows. A general linear models procedure was used to analyze the data (SAS Version 9.2; SAS Institute Inc., Cary, NC). Means were separated using Tukey's honestly significant difference test $(P=0.05)$.

\section{Results}

There were no significant interactions between organic amendments/herbicides and flame. Because nearly every parameter differed significantly between the two iterations, data were analyzed separately and results are 
presented by iteration. Weed species present in the plots for both iterations included the grass weeds Italian ryegrass (Lolium perenne ssp. multiflorum) and annual bluegrass and the broadleaf weeds common chickweed, common lambsquarters, henbit, shepherd'spurse, pale smartweed, and ladysthumb (Polygonum lapathifolium and $P$. persicaria, respectively).

Effects of flaming. In Iteration 1, flaming PRETR once slightly increased grass weed rating (1.8) in June compared with rototilling alone or flaming twice (1.4 for all), but there was no significant difference between treatments by September (Table 2). Broadleaf weed control in both of the twice-flamed strawberry plots was slightly better (rating of 1.0) than in rototilled plots (1.2) by June. In Iteration 2, grass weed rating in June was slightly greater in plots flamed once PRETR (2.9) compared with rototilling alone or flaming twice (ranging from 1.8 to 2.3 ) (Table 2). Broadleaf weed control with PRETR once or PRETR + POSTR was poorer (2.3) than from PRETR + PRETR or rototilling (1.6) at the June evaluation. By September, there was no significant effect of any flaming treatment on grass or broadleaf weeds.

Strawberry plots flamed once PRETR took $12 \mathrm{~h} \cdot \mathrm{ha}^{-1} /$ person longer to weed than rototilled plots in June of Iteration 1 (Table 3). In Iteration 2, flaming treatments resulted in similar weeding times as rototilled plots, although flaming once PRETR or PRETR + PRETR reduced weeding time compared with PRETR + POSTR. There was no difference in weeding times in July or August in either iteration. Weeding in September took two to 10 times longer than in previous months with strawberry flamed once PRETR or rototilled taking $\approx 30 \mathrm{~h} \cdot \mathrm{ha}^{-1} /$ person less time to weed than PRETR + PRETR in Iteration 1 and PRETR + PRETR and PRETR + POSTR flamed strawberry taking $\approx 38 \mathrm{~h} \cdot \mathrm{ha}^{-1} /$ person less time to weed than rototilled strawberry in Iteration 2. Flamed plots took less time to weed than rototilled plots in March of Iteration 1, whereas there was no significant difference among treatments in March of Iteration 2. Flaming PRETR once reduced weeding time compared with rototilled strawberry in April of both iterations. Total weeding time in Iteration 1 was 714 $\mathrm{h} \cdot \mathrm{ha}^{-1} /$ person in plots flamed once PRETR, $12 \%$ less that for rototilled plots $\left(808 \mathrm{~h} \cdot \mathrm{ha}^{-1} /\right.$ person). In Iteration 2 , total weeding time was reduced an average of $10 \%$ by flaming treatments (ranging from 1035 to $1055 \mathrm{~h} \cdot \mathrm{ha}^{-1}$ / person) compared with rototilling alone (1164 h $\cdot \mathrm{ha}^{-1} /$ person).

The number of strawberry leaves and leaf area on first-year plants was reduced in rototilled plots compared with flamed strawberries in Iteration 1 (Table 4). Runner number was also greater in plots flamed once PRETR or PRETR + PRETR than in rototilled plots, although daughter plant production was not significantly affected by flaming. In Iteration 2, the number of daughter plants was greater for strawberry flamed PRETR once compared with PRETR + POSTR flaming

Table 1. Monthly precipitation ${ }^{z}$ received at Washington State University Northwestern Washington Research and Extension Center during the trial (June 2000 through July 2002).

\begin{tabular}{|c|c|c|c|c|c|}
\hline \multicolumn{2}{|r|}{2000} & \multicolumn{2}{|r|}{2001} & \multicolumn{2}{|r|}{2002} \\
\hline Month & Precipitation $(\mathrm{mm})$ & Month & Precipitation $(\mathrm{mm})$ & Month & $\begin{array}{l}\text { Precipitation }(\mathrm{mm}) \\
\end{array}$ \\
\hline Jan. & 101 & Jan. & 91 & Jan. & 106 \\
\hline Feb. & 57 & Feb. & 34 & Feb. & 75 \\
\hline Mar. & 83 & Mar. & 87 & Mar. & 81 \\
\hline Apr. & 90 & Apr. & 84 & Apr. & 60 \\
\hline May & 116 & May & 47 & May & 52 \\
\hline June & 49 & June & 114 & June & 51 \\
\hline July & 32 & July & 14 & July & 35 \\
\hline Aug. & 32 & Aug. & 43 & Aug. & 9 \\
\hline Sept. & 43 & Sept. & 21 & Sept. & 45 \\
\hline Oct. & 43 & Oct. & 150 & Oct. & 27 \\
\hline Nov. & 41 & Nov. & 89 & Nov. & 45 \\
\hline Dec. & 56 & Dec. & 114 & Dec. & 48 \\
\hline Total & 744 & Total & 888 & Total & 633 \\
\hline
\end{tabular}

${ }^{2}$ Precipitation recorded with an automated weather station.

Table 2. Weed rating (0 to 5) after pre-transplant or post-transplant flaming or rototilling in 'Hood' strawberry.

\begin{tabular}{|c|c|c|c|c|}
\hline \multirow[b]{2}{*}{ Treatment $^{\mathrm{z}}$} & \multicolumn{2}{|c|}{ Grass weed rating $^{y}$} & \multicolumn{2}{|c|}{ Broadleaf weed rating $^{y}$} \\
\hline & June & Sept. & June & Sept. \\
\hline \multicolumn{5}{|c|}{ Iteration 1} \\
\hline Flame PRETR + PRETR & $1.4 \mathrm{~b}^{\mathrm{x}}$ & 2.5 & $1.0 \mathrm{~b}$ & 2.5 \\
\hline Flame PRETR + POSTR & $1.4 \mathrm{~b}$ & 2.3 & $1.0 \mathrm{~b}$ & 2.6 \\
\hline Flame PRETR & $1.8 \mathrm{a}$ & 2.1 & $1.4 \mathrm{a}$ & 2.6 \\
\hline Rototill PRETR & $1.4 \mathrm{~b}$ & 1.7 & $1.2 \mathrm{a}$ & 2.5 \\
\hline \multicolumn{5}{|c|}{ Iteration 2} \\
\hline Flame PRETR + PRETR & $2.3 \mathrm{~b}$ & 2.8 & $1.6 \mathrm{~b}$ & 3.7 \\
\hline Flame PRETR + POSTR & $1.9 \mathrm{~b}$ & 2.7 & $2.3 \mathrm{a}$ & 3.5 \\
\hline Flame PRETR & $2.9 \mathrm{a}$ & 2.9 & $2.3 \mathrm{a}$ & 4.1 \\
\hline Rototill PRETR & $1.8 \mathrm{~b}$ & 3.1 & $1.6 \mathrm{~b}$ & 3.9 \\
\hline
\end{tabular}

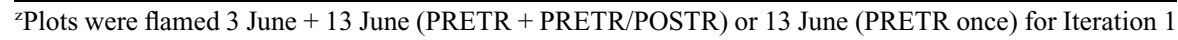
(2000); 18 May + 29 May (PRETR + PRETR), 18 May + 30 May (PRETR + POSTR), or 29 May (PRETR once) for Iteration 2 (2001); plots were rototilled 13 June 2000 PRETR for Iteration 1 and 29 May 2001 for Iteration 2.

${ }^{\mathrm{y}}$ Weed ratings ( 0 to $5 ; 0=$ no weeds, $5=$ high weed density) visually estimated 27 June and 14 Sept. 2000 for Iteration 1 and 15 June and 10 Sept. 2001 for Iteration 2.

${ }^{\mathrm{x}}$ Means within a column and iteration followed by the same letter or not followed by a letter are not significantly different (Tukey's honestly significant difference test at $P=0.05$ ).

Table 3. Monthly and total weeding time $\mathrm{z}^{\mathrm{z}}\left(\mathrm{h} \cdot \mathrm{ha} \mathrm{a}^{-1} /\right.$ person) for 'Hood' strawberry after pre-transplant or post-transplant flaming or rototilling.

\begin{tabular}{lccccccc}
\hline Treatment $^{\mathrm{y}}$ & June & July & Aug. & Sept. & Mar. & Apr. & Total \\
\hline Flame PRETR + PRETR & $18 \mathrm{~b}^{\mathrm{x}}$ & 21 & 47 & $266 \mathrm{a}$ & $297 \mathrm{~b}$ & $121 \mathrm{ab}$ & $768 \mathrm{ab}$ \\
Flame PRETR + POSTR & $22 \mathrm{~b}$ & 25 & 53 & $251 \mathrm{ab}$ & $300 \mathrm{~b}$ & $123 \mathrm{ab}$ & $773 \mathrm{ab}$ \\
Flame PRETR & $33 \mathrm{a}$ & 22 & 47 & $228 \mathrm{~b}$ & $270 \mathrm{~b}$ & $114 \mathrm{~b}$ & $714 \mathrm{~b}$ \\
Rototill PRETR & $21 \mathrm{~b}$ & 21 & 48 & $230 \mathrm{~b}$ & $353 \mathrm{a}$ & $136 \mathrm{a}$ & $808 \mathrm{a}$ \\
& \multicolumn{7}{c}{ Iteration 2} \\
Flame PRETR + PRETR & $41 \mathrm{~b}$ & 50 & 108 & $267 \mathrm{~b}$ & 258 & $330 \mathrm{ab}$ & $1055 \mathrm{~b}$ \\
Flame PRETR + POSTR & $52 \mathrm{a}$ & 48 & 105 & $267 \mathrm{~b}$ & 257 & $317 \mathrm{ab}$ & $1044 \mathrm{~b}$ \\
Flame PRETR & $41 \mathrm{~b}$ & 49 & 106 & $292 \mathrm{ab}$ & 259 & $290 \mathrm{~b}$ & $1035 \mathrm{~b}$ \\
Rototill PRETR & $44 \mathrm{ab}$ & 53 & 113 & $305 \mathrm{a}$ & 291 & $358 \mathrm{a}$ & $1164 \mathrm{a}$ \\
\hline
\end{tabular}

${ }^{2}$ Strawberries were hand-weeded six times from transplanting until berry harvest: June, July, Aug., and Sept. of Year 1 and Mar. and Apr. of Year 2.

yPlots were flamed 3 June +13 June (PRETR + PRETR/POSTR) or 13 June (PRETR once) for Iteration 1 (2000); 18 May + 29 May (PRETR + PRETR), 18 May + 30 May (PRETR + POSTR), or 29 May (PRETR once) for Iteration 2 (2001); plots were rototilled 13 June 2000 PRETR for Iteration 1 and 29 May 2001 for Iteration 2.

${ }^{x}$ Means within a column and iteration followed by the same letter or not followed by a letter are not significantly different (Tukey's honestly significant difference test at $P=0.05$ ).

(4.7 and 3.5 daughters, respectively). Leaf area was less in twice-flamed strawberry than in strawberry flamed PRETR once. Rototilling plots in Iteration 1 resulted in $\approx 20 \%$ lower berry yield and individual fruit $\approx 1 \mathrm{~g}$ lighter than strawberries produced in flamed plots (Table 4); there was no significant effect of flaming treatment on strawberry yield or individual fruit weight in Iteration 2.

Effects of organic amendments and herbicides. No treatment in Iteration 1 reduced grass weed rating compared with the nontreated control 
plots at either the June or September evaluation (Table 5). Treatment with oxyfluorfen or oxyfluorfen + pendimethalin reduced grass weed rating (1.0 and 1.2, respectively) compared with the low rate of CGM or pendimethalin alone (2.0 and 1.8, respectively), whereas oxyfluorfen alone also reduced grass rating compared the high rate of CGM (1.7). Broadleaf weed rating at the June evaluation was reduced by both MSM treatments and by both treatments containing oxyfluorfen (1.0 for all) as compared with nontreated control plots (1.3). In Iteration 2, grass weed rating was reduced only by oxyfluorfen alone (1.1) compared with the nontreated control (2.7) at the June evaluation (Table 5). By September, only pendimethalin (2.0) had reduced grass rating compared with nontreated plots (3.4). Broadleaf weed rating was reduced by pendimethalin (1.8), oxyfluorfen (0.3), oxyfluorfen + pendimethalin (0.4), and both low and high glucosinolate MSM treatments (1.9 and 1.4, respectively) at the June evaluation compared with nontreated control plots, but only pendimethalin (2.9) continued to suppress broadleaf weed rating in September compared with the nontreated control (4.3).

Weeding time for plots treated with amendment/herbicides in Iteration 1 did not differ from nontreated control plots in June and July (Table 6). Weeding time in August was reduced $\approx 45 \%$ by the two oxyfluorfen treatments (37 and $34 \mathrm{~h} \cdot \mathrm{ha}^{-1} /$ person) compared with the nontreated control plots $\left(63 \mathrm{~h} \cdot \mathrm{ha}^{-1} /\right.$ person). Weeding time was increased by CGM at $487 \mathrm{~kg} \cdot \mathrm{ha}^{-1}$ in September, taking $54 \mathrm{~h} \cdot \mathrm{ha}^{-1 /}$ person longer than for nontreated plots. No treatment was still providing weed control by March. Dormant-season treatments resulted in shorter weeding times for both types of MSM and all herbicides in April. Total weeding time in Iteration 1 was not significantly reduced by any treatment compared with the nontreated control. Total weeding time for CGM at $487 \mathrm{~kg} \cdot \mathrm{ha}^{-1}$ was $\approx 18 \%$ (161 h.ha $\mathrm{ha}^{-1} /$ person) longer than for the three herbicide treatments or low-glucosinolate MSM, however.

In Iteration 2, June weeding time was reduced $43 \%$ ( $30 \mathrm{~h} \cdot \mathrm{ha}^{-1} /$ person) by treatment with high-glucosinolate MSM and by the two oxyfluorfen treatments as compared with nontreated plots (Table 6), whereas treatment with either rate of CGM or WG increased June weeding time by as much as $60 \%$ in comparison with those treatments. All herbicides reduced July weeding time from the nontreated control plots and compared with all organic amendments except high-glucosinolate MSM. In August, weeding WG plots still took $30 \%\left(39 \mathrm{~h} \cdot \mathrm{ha}^{-1} /\right.$ person $)$ longer than did the two pendimethalin-treated plots. By September, only oxyfluorfen + pendimethalin reduced weeding time compared with the nontreated control plots (233 and $301 \mathrm{~h} \cdot \mathrm{ha}^{-1 /}$ person, respectively). After dormant-season applications, March weeding times increased for plots treated with $\mathrm{WG}$ and CGM at $974 \mathrm{~kg} \cdot \mathrm{ha}^{-1}$ as long as $425 \mathrm{~h} \cdot \mathrm{ha}^{-1} /$ person with WG compared with $285 \mathrm{~h} \cdot \mathrm{ha}^{-1} /$ person for nontreated control plots; oxyfluorfen +

Table 4. 'Hood' strawberry growth at the end of the first growing season ${ }^{z}$ and second-year berry yield ${ }^{y}$ after pre-transplant or post-transplant flaming or rototilling.

\begin{tabular}{|c|c|c|c|c|c|c|}
\hline Treatment $^{\mathrm{x}}$ & $\begin{array}{l}\text { Leaves } \\
\text { per plant }\end{array}$ & $\begin{array}{l}\text { Runners } \\
\text { per plant }\end{array}$ & $\begin{array}{l}\text { Daughters } \\
\text { per plant }\end{array}$ & $\begin{array}{l}\text { Leaf area } \\
\left(\mathrm{cm}^{2} / \text { plant }\right)\end{array}$ & $\begin{array}{l}\text { Total wt } \\
\left(\mathrm{kg} \cdot \mathrm{ha}^{-1}\right)\end{array}$ & $\begin{array}{l}\text { Avg individual } \\
\text { fruit wt }(\mathrm{g})\end{array}$ \\
\hline \multicolumn{7}{|c|}{ Iteration 1} \\
\hline Flame PRETR + PRETR & $13.8 \mathrm{a}^{\mathrm{w}}$ & $5.3 \mathrm{a}$ & 4.0 & $1,013 \mathrm{a}$ & $9,606 \mathrm{ab}$ & $15.7 \mathrm{a}$ \\
\hline Flame PRETR + POSTR & $14.4 \mathrm{a}$ & $5.1 \mathrm{ab}$ & 3.9 & $1,037 \mathrm{a}$ & $9,910 \mathrm{a}$ & $16.1 \mathrm{a}$ \\
\hline Flame PRETR & $14.0 \mathrm{a}$ & $5.2 \mathrm{a}$ & 3.9 & $1,030 \mathrm{a}$ & $9,087 \mathrm{~b}$ & $15.7 \mathrm{a}$ \\
\hline Rototill PRETR & $11.9 \mathrm{~b}$ & $4.5 \mathrm{~b}$ & 3.3 & $852 \mathrm{~b}$ & $7,808 \mathrm{c}$ & $14.9 \mathrm{~b}$ \\
\hline \multicolumn{7}{|c|}{ Iteration 2} \\
\hline Flame PRETR + PRETR & 21.0 & 7.1 & $4.0 \mathrm{ab}$ & $1,604 \mathrm{~b}$ & 9,797 & 14.3 \\
\hline Flame PRETR + POSTR & 20.2 & 6.8 & $3.5 \mathrm{~b}$ & $1,555 \mathrm{~b}$ & 10,159 & 14.5 \\
\hline Flame PRETR & 21.1 & 7.3 & $4.7 \mathrm{a}$ & $1,812 \mathrm{a}$ & 9,974 & 14.7 \\
\hline Rototill PRETR & 20.1 & 7.0 & $4.0 \mathrm{ab}$ & $1,637 \mathrm{ab}$ & 9,568 & 14.5 \\
\hline
\end{tabular}

${ }^{2}$ Strawberry growth measured 5 to 7 Sept. 2000 for Iteration 1 and 14 to 15 Aug. 2001 for Iteration 2. ${ }^{\mathrm{y} B e r r i e s}$ were picked three times: 21 June, 28 June, and 2 July 2001 for Iteration 1 and 24 June, 1 July, and 10 July 2002 for Iteration 2.

${ }^{x}$ Plots were flamed 3 June +13 June (PRETR + PRETR/POSTR) or 13 June (PRETR once) for Iteration 1 (2000); 18 May + 29 May (PRETR + PRETR), 18 May + 30 May (PRETR + POSTR), or 29 May (PRETR once) for Iteration 2 (2001); plots were rototilled 13 June 2000 PRETR for Iteration 1 and 29 May 2001 for Iteration 2.

"Means within a column and iteration followed by the same letter or not followed by a letter are not significantly different (Tukey's honestly significant difference test at $P=0.05$ ).

Table 5. Weed rating ( 0 to 5 ) after post-transplant treatment with organic amendment or herbicide in 'Hood' strawberry.

\begin{tabular}{|c|c|c|c|c|c|}
\hline \multirow[b]{2}{*}{ Treatment $^{\mathrm{z}}$} & \multirow{2}{*}{$\begin{array}{l}\text { Application rate } \\
\left(\mathrm{kg} \cdot \mathrm{ha}^{-1}\right)\end{array}$} & \multicolumn{2}{|c|}{ Grass weed rating $^{\mathrm{y}}$} & \multicolumn{2}{|c|}{$\underline{\text { Broadleaf weed rating }}$} \\
\hline & & June & Sept. & June & Sept. \\
\hline \multicolumn{6}{|c|}{ Iteration 1} \\
\hline Corn gluten meal & 487 & $2.0 \mathrm{a}^{\mathrm{x}}$ & 2.4 & $1.3 \mathrm{ab}$ & 3.0 \\
\hline Corn gluten meal & 974 & $1.7 \mathrm{abc}$ & 2.9 & $1.3 \mathrm{ab}$ & 2.8 \\
\hline Wheat gluten & 700 & $1.4 \mathrm{a}-\mathrm{d}$ & 1.8 & $1.4 \mathrm{a}$ & 2.8 \\
\hline $\begin{array}{l}\text { Mustard seed meal } \\
\text { (low glucosinolate) }\end{array}$ & 644 & $1.3 \mathrm{bcd}$ & 1.8 & $1.0 \mathrm{c}$ & 2.9 \\
\hline $\begin{array}{l}\text { Mustard seed meal } \\
\text { (high glucosinolate) }\end{array}$ & 644 & $1.3 \mathrm{bcd}$ & 1.8 & $1.0 \mathrm{c}$ & 2.9 \\
\hline Pendimethalin & 2.24 a.i. & $1.8 \mathrm{ab}$ & 1.8 & $1.1 \mathrm{bc}$ & 1.8 \\
\hline Oxyfluorfen & 0.43 a.i. & $1.0 \mathrm{~d}$ & 2.7 & $1.0 \mathrm{c}$ & 1.9 \\
\hline Oxyfluorfen + pendimethalin & 0.28 a.i. +1.12 a.i. & $1.2 \mathrm{~cd}$ & 2.5 & $1.0 \mathrm{c}$ & 1.8 \\
\hline Nontreated & - & $1.6 \mathrm{a}-\mathrm{d}$ & 1.6 & $1.3 \mathrm{ab}$ & 3.0 \\
\hline \multicolumn{6}{|c|}{ Iteration 2} \\
\hline Corn gluten meal & 487 & $2.4 \mathrm{a}$ & $2.7 \mathrm{ab}$ & $2.8 \mathrm{ab}$ & $3.8 \mathrm{ab}$ \\
\hline Corn gluten meal & 974 & $2.5 \mathrm{a}$ & $3.1 \mathrm{a}$ & $2.9 \mathrm{a}$ & $4.0 \mathrm{a}$ \\
\hline Wheat gluten & 700 & $2.8 \mathrm{a}$ & $3.5 \mathrm{a}$ & $3.1 \mathrm{a}$ & $4.2 \mathrm{a}$ \\
\hline $\begin{array}{l}\text { Mustard seed meal } \\
\text { (low glucosinolate) }\end{array}$ & 644 & $2.2 \mathrm{a}$ & $3.2 \mathrm{a}$ & $1.9 \mathrm{bc}$ & $3.8 \mathrm{ab}$ \\
\hline $\begin{array}{l}\text { Mustard seed meal } \\
\text { (high glucosinolate) }\end{array}$ & 644 & $1.9 \mathrm{ab}$ & $2.8 \mathrm{ab}$ & $1.4 \mathrm{c}$ & $3.6 \mathrm{ab}$ \\
\hline Pendimethalin & 2.24 a.i. & $2.7 \mathrm{a}$ & $2.0 \mathrm{~b}$ & $1.8 \mathrm{c}$ & $2.9 \mathrm{~b}$ \\
\hline Oxyfluorfen & 0.43 a.i. & $1.1 \mathrm{~b}$ & $2.7 \mathrm{ab}$ & $0.3 \mathrm{~d}$ & $3.9 \mathrm{ab}$ \\
\hline Oxyfluorfen + pendimethalin & 0.28 a.i. +1.12 a.i. & $1.9 \mathrm{ab}$ & $2.6 \mathrm{ab}$ & $0.4 \mathrm{~d}$ & $3.7 \mathrm{ab}$ \\
\hline Nontreated & - & $2.7 \mathrm{a}$ & $3.4 \mathrm{a}$ & $3.1 \mathrm{a}$ & $4.3 \mathrm{a}$ \\
\hline
\end{tabular}

${ }^{2}$ POSTR treatments applied 13 June 2000 for Iteration 1 and 30 May 2001 for Iteration 2.

${ }^{y}$ Weed ratings ( 0 to $5 ; 0=$ no weeds, $5=$ high weed density) visually estimated 27 June and 14 Sept. 2000 for Iteration 1 and 15 June and 10 Sept. 2001 for Iteration 2.

${ }^{x}$ Means within a column and iteration followed by the same letter or not followed by a letter are not significantly different (Tukey's honestly significant difference test at $P=0.05$ ).

pendimethalin reduced March weeding time $52 \%$ (151 h.ha $\mathrm{h}^{-1} /$ person) at that timing. By April, pendimethalin alone and CGM at $974 \mathrm{~kg} \cdot \mathrm{ha}^{-1}$ had reduced weeding time compared with the nontreated control plots. Total weeding time was reduced $\approx 14 \%$ (up to $350 \mathrm{~h} \cdot \mathrm{ha}^{-1} /$ person) for the pendimethalin treatments and high-glucosinolate MSM compared with nontreated control plots.

The number of strawberry leaves, runners, and daughter plants on first-year plants treated with amendments/herbicides did not differ from nontreated strawberry in
Iteration 1 (Table 7). Leaf area was reduced by oxyfluorfen + pendimethalin compared with nontreated strawberries $\left(802\right.$ and $1086 \mathrm{~cm}^{2} /$ plant, respectively). First-year strawberry growth was generally increased with organic amendments in Iteration 2, although only significantly so by CGM at $487 \mathrm{~kg} \cdot \mathrm{ha}^{-1}$ for number of runners and by low-glucosinolate MSM for number of runners and daughter plants (Table 7). Conversely, all the synthetic herbicides reduced number of leaves and leaf area, whereas oxyfluorfen also reduced runner number. 
Table 6. Monthly and total weeding time $\mathrm{z}^{\mathrm{z}}$ (h.ha $\mathrm{h}^{-1}$ person) for 'Hood' strawberry treated with organic amendment or herbicide.

\begin{tabular}{|c|c|c|c|c|c|c|c|c|}
\hline Treatment $^{\mathrm{y}}$ & Application rate $\left(\mathrm{kg} \cdot \mathrm{ha}^{-1}\right)$ & June & July & Aug. & Sept. & Mar. & Apr. & Total \\
\hline \multicolumn{9}{|c|}{ Iteration 1} \\
\hline Corn gluten meal & 487 & $37 a^{x}$ & $27 \mathrm{a}$ & $60 \mathrm{ab}$ & $288 \mathrm{a}$ & 313 & $154 \mathrm{a}$ & $880 \mathrm{a}$ \\
\hline Corn gluten meal & 974 & $31 \mathrm{ab}$ & $25 \mathrm{ab}$ & $45 \mathrm{abc}$ & $250 \mathrm{ab}$ & 309 & $178 \mathrm{a}$ & $838 \mathrm{ab}$ \\
\hline Wheat gluten & 700 & $27 \mathrm{abc}$ & $27 \mathrm{a}$ & $51 \mathrm{abc}$ & $242 \mathrm{abc}$ & 287 & $158 \mathrm{a}$ & $792 \mathrm{ab}$ \\
\hline $\begin{array}{l}\text { Mustard seed meal } \\
\text { (low glucosinolate) }\end{array}$ & 644 & $17 \mathrm{bc}$ & $22 \mathrm{ab}$ & $58 \mathrm{ab}$ & $249 \mathrm{ab}$ & 285 & $103 \mathrm{~b}$ & $731 \mathrm{~b}$ \\
\hline $\begin{array}{l}\text { Mustard seed meal } \\
\text { (high glucosinolate) }\end{array}$ & 644 & $19 \mathrm{bc}$ & $19 \mathrm{ab}$ & $47 \mathrm{abc}$ & $249 \mathrm{ab}$ & 313 & $98 \mathrm{~b}$ & $745 \mathrm{ab}$ \\
\hline Pendimethalin & 2.24 a.i. & $28 \mathrm{abc}$ & $21 \mathrm{ab}$ & $42 \mathrm{bc}$ & $201 \mathrm{c}$ & 304 & $104 \mathrm{~b}$ & $699 \mathrm{~b}$ \\
\hline Oxyfluorfen & 0.43 a.i. & $15 \mathrm{c}$ & $18 \mathrm{~b}$ & $37 \mathrm{c}$ & $233 \mathrm{bc}$ & 327 & $89 \mathrm{~b}$ & $719 \mathrm{~b}$ \\
\hline Oxyfluorfen + pendimethalin & 0.28 a.i. +1.12 a.i. & $14 \mathrm{c}$ & $18 \mathrm{~b}$ & $34 \mathrm{c}$ & $245 \mathrm{abc}$ & 336 & $81 \mathrm{~b}$ & $728 \mathrm{~b}$ \\
\hline Nontreated & - & 22 abc & $22 \mathrm{ab}$ & $63 \mathrm{a}$ & $234 \mathrm{bc}$ & 270 & $146 \mathrm{a}$ & $758 \mathrm{ab}$ \\
\hline \multicolumn{9}{|c|}{ Iteration 2} \\
\hline Corn gluten meal & 487 & $51 \mathrm{abc}$ & $50 \mathrm{~b}$ & $102 \mathrm{bc}$ & $298 \mathrm{a}$ & $336 \mathrm{ab}$ & $302 \mathrm{bc}$ & $1139 \mathrm{bc}$ \\
\hline Corn gluten meal & 974 & $69 \mathrm{a}$ & $52 \mathrm{~b}$ & $108 \mathrm{abc}$ & $284 \mathrm{ab}$ & 393 a & $281 \mathrm{~cd}$ & $1187 \mathrm{ab}$ \\
\hline Wheat gluten & 700 & $58 \mathrm{ab}$ & $73 \mathrm{a}$ & $131 \mathrm{a}$ & $295 \mathrm{a}$ & $425 \mathrm{a}$ & $324 \mathrm{abc}$ & $1305 \mathrm{a}$ \\
\hline $\begin{array}{l}\text { Mustard seed meal } \\
\text { (low glucosinolate) }\end{array}$ & 644 & $37 \mathrm{~cd}$ & $61 \mathrm{ab}$ & $110 \mathrm{abc}$ & $304 \mathrm{a}$ & $233 \mathrm{~cd}$ & $351 \mathrm{abc}$ & $1096 \mathrm{bc}$ \\
\hline $\begin{array}{l}\text { Mustard seed meal } \\
\text { (high glucosinolate) }\end{array}$ & 644 & $31 \mathrm{~d}$ & $49 \mathrm{bc}$ & $110 \mathrm{abc}$ & $277 \mathrm{ab}$ & $191 \mathrm{~cd}$ & $342 \mathrm{abc}$ & $1001 \mathrm{~cd}$ \\
\hline Pendimethalin & 2.24 a.i. & 43 bcd & $35 \mathrm{~cd}$ & $88 \mathrm{c}$ & $263 \mathrm{ab}$ & $205 \mathrm{~cd}$ & $211 \mathrm{~d}$ & $846 \mathrm{~d}$ \\
\hline Oxyfluorfen & 0.43 a.i. & $29 \mathrm{~d}$ & $34 \mathrm{~d}$ & $118 \mathrm{ab}$ & $289 \mathrm{ab}$ & $189 \mathrm{~cd}$ & $392 \mathrm{a}$ & $1054 \mathrm{bc}$ \\
\hline Oxyfluorfen + pendimethalin & 0.28 a.i. +1.12 a.i. & $29 \mathrm{~d}$ & $31 \mathrm{~d}$ & 96 bc & $233 \mathrm{~b}$ & $134 \mathrm{~d}$ & $324 \mathrm{abc}$ & $848 \mathrm{~d}$ \\
\hline Nontreated & - & $52 \mathrm{abc}$ & $62 \mathrm{ab}$ & $109 \mathrm{abc}$ & $301 \mathrm{a}$ & $285 \mathrm{bc}$ & $386 \mathrm{ab}$ & $1196 \mathrm{ab}$ \\
\hline
\end{tabular}

${ }^{\mathrm{z}}$ Strawberries were hand-weeded six times from transplanting until berry harvest: June, July, Aug., and Sept. of Year 1 and Mar. and Apr. of Year 2.

yPOSTR treatments applied 13 June 2000 for Iteration 1 and 30 May 2001 for Iteration 2; dormant-season treatments applied 23 Mar. 2001 for Iteration 1 and 1 Feb. 2002 for Iteration 2.

${ }^{x}$ Means within a column and iteration followed by the same letter or not followed by a letter are not significantly different (Tukey's honestly significant difference test at $P=0.05)$.

Table 7. 'Hood' strawberry growth at the end of the first growing season ${ }^{\mathrm{z}}$ and second-year berry yield and individual fruit weight ${ }^{\mathrm{y}}$ after post-transplant treatment with organic amendment or herbicide.

\begin{tabular}{|c|c|c|c|c|c|c|c|}
\hline Treatment $^{\mathrm{x}}$ & Application rate $\left(\mathrm{kg} \cdot \mathrm{ha}^{-1}\right)$ & $\begin{array}{c}\text { Leaves } \\
\text { per plant }\end{array}$ & $\begin{array}{l}\text { Runners } \\
\text { per plant }\end{array}$ & $\begin{array}{l}\text { Daughters } \\
\text { per plant }\end{array}$ & $\begin{array}{c}\text { Leaf area } \\
\left(\mathrm{cm}^{2} / \text { plant }\right)\end{array}$ & $\begin{array}{c}\text { Yield } \\
\left(\mathrm{kg} \cdot \mathrm{ha}^{-1}\right)\end{array}$ & $\begin{array}{l}\text { Avg individual } \\
\text { fruit wt }(\mathrm{g})\end{array}$ \\
\hline \multicolumn{8}{|c|}{ Iteration 1} \\
\hline Corn gluten meal & 487 & $14.7^{\mathrm{w}}$ & $5.6 \mathrm{a}$ & $5.0 \mathrm{a}$ & $1119 \mathrm{a}$ & $9,504 \mathrm{bcd}$ & $16.4 \mathrm{a}$ \\
\hline Corn gluten meal & 974 & 13.5 & $5.2 \mathrm{ab}$ & $4.5 \mathrm{ab}$ & $1046 \mathrm{ab}$ & $10,897 \mathrm{a}$ & $16.2 \mathrm{a}$ \\
\hline Wheat gluten & 700 & 12.4 & $4.9 \mathrm{ab}$ & $3.6 \mathrm{abc}$ & $942 \mathrm{ab}$ & $10,775 \mathrm{ab}$ & $16.5 \mathrm{a}$ \\
\hline $\begin{array}{l}\text { Mustard seed meal } \\
\text { (low glucosinolate) }\end{array}$ & 644 & 13.8 & $5.7 \mathrm{a}$ & $3.9 \mathrm{ab}$ & $1087 \mathrm{a}$ & $10,097 \mathrm{abc}$ & $15.6 \mathrm{ab}$ \\
\hline $\begin{array}{l}\text { Mustard seed meal } \\
\text { (high glucosinolate) }\end{array}$ & 644 & 12.9 & $4.9 \mathrm{ab}$ & $3.8 \mathrm{abc}$ & $917 \mathrm{ab}$ & 8,160 de & $14.8 \mathrm{~b}$ \\
\hline Pendimethalin & 2.24 a.i. & 14.0 & $4.3 \mathrm{~b}$ & $2.9 \mathrm{bc}$ & $916 \mathrm{ab}$ & $8,588 \mathrm{de}$ & $15.5 \mathrm{ab}$ \\
\hline Oxyfluorfen & 0.43 a.i. & 13.4 & $4.9 \mathrm{ab}$ & $4.1 \mathrm{ab}$ & $932 \mathrm{ab}$ & $7,315 \mathrm{e}$ & $14.8 \mathrm{~b}$ \\
\hline Oxyfluorfen + pendimethalin & 0.28 a.i. +1.12 a.i. & 12.7 & $4.2 \mathrm{~b}$ & $2.2 \mathrm{c}$ & 802 b & $7,287 \mathrm{e}$ & $14.5 \mathrm{~b}$ \\
\hline Nontreated & - & 14.3 & $5.4 \mathrm{ab}$ & $3.8 \mathrm{abc}$ & $1086 \mathrm{a}$ & $9,305 \mathrm{~cd}$ & $16.1 \mathrm{a}$ \\
\hline \multicolumn{8}{|c|}{ Iteration 2} \\
\hline Corn gluten meal & 487 & $23.0 \mathrm{a}$ & $8.3 \mathrm{a}$ & $4.8 \mathrm{abc}$ & $2020 \mathrm{a}$ & $10,761 \mathrm{ab}$ & 14.4 \\
\hline Corn gluten meal & 974 & $21.8 \mathrm{ab}$ & $8.0 \mathrm{ab}$ & $5.1 \mathrm{ab}$ & $1812 \mathrm{a}$ & $9,771 \mathrm{abc}$ & 14.2 \\
\hline Wheat gluten & 700 & $20.8 \mathrm{abc}$ & $7.4 \mathrm{abc}$ & $4.3 \mathrm{a}-\mathrm{d}$ & $1738 \mathrm{a}$ & $10,866 \mathrm{a}$ & 15.0 \\
\hline $\begin{array}{l}\text { Mustard seed meal } \\
\text { (low glucosinolate) }\end{array}$ & 644 & $23.7 \mathrm{a}$ & $8.6 \mathrm{a}$ & $5.4 \mathrm{a}$ & $2033 \mathrm{a}$ & $9,414 \mathrm{bc}$ & 14.6 \\
\hline $\begin{array}{l}\text { Mustard seed meal } \\
\text { (high glucosinolate) }\end{array}$ & 644 & $21.3 \mathrm{abc}$ & $7.2 \mathrm{abc}$ & $4.1 \mathrm{a}-\mathrm{e}$ & $1683 \mathrm{a}$ & $9,651 \mathrm{abc}$ & 14.0 \\
\hline Pendimethalin & 2.24 a.i. & $18.0 \mathrm{bcd}$ & $5.8 \mathrm{de}$ & $3.0 \mathrm{de}$ & $1320 \mathrm{~b}$ & $9,559 \mathrm{abc}$ & 14.6 \\
\hline Oxyfluorfen & 0.43 a.i. & $16.7 \mathrm{~d}$ & $5.2 \mathrm{e}$ & $2.6 \mathrm{e}$ & $1272 \mathrm{~b}$ & $9,596 \mathrm{abc}$ & 14.7 \\
\hline Oxyfluorfen + pendimethalin & 0.28 a.i. +1.12 a.i. & $17.9 \mathrm{~cd}$ & $6.1 \mathrm{cde}$ & $3.5 \mathrm{cde}$ & $1277 \mathrm{~b}$ & $9,048 \mathrm{c}$ & 14.8 \\
\hline Nontreated & - & $22.3 \mathrm{a}$ & $6.8 \mathrm{bcd}$ & $3.8 \mathrm{~b}-\mathrm{e}$ & $1712 \mathrm{a}$ & $10,205 \mathrm{abc}$ & 14.1 \\
\hline
\end{tabular}

z'trawberry growth measured 5 to 7 Sept. 2000 for Iteration 1 and 14 to 15 Aug. 2001 for Iteration 2.

y Berries were picked 21 June, 28 June, and 2 July 2001 for Iteration 1 and 24 June, 1 July, and 10 July 2002 for Iteration 2.

xPOSTR treatments applied 13 June 2000 for Iteration 1 and 30 May 2001 for Iteration 2.

${ }^{\text {w}}$ Means within a column and iteration followed by the same letter or not followed by a letter are not significantly different (Tukey's honestly significant difference test at $P=0.05$ ).

Strawberry yield was increased $\approx 14 \%$ by CGM at the high rate, WG, and lowglucosinolate MSM (averaging 10,590 kg.ha ${ }^{-1}$ ) compared with nontreated strawberry (9305 $\mathrm{kg} \cdot \mathrm{ha}^{-1}$ ) in Iteration 1 (Table 7). Oxyfluorfen and oxyfluorfen + pendimethalin reduced strawberry yield by $\approx 20 \%$ (7315 and 7287 $\mathrm{kg} \cdot \mathrm{ha}^{-1}$, respectively) and average individual fruit weight by $\approx 9 \%$ (14.8 and $14.5 \mathrm{~g} /$ fruit) compared with nontreated strawberry (16.1 $\mathrm{g} /$ fruit); high-glucosinolate MSM also reduced average individual fruit weight to $14.8 \mathrm{~g} /$ fruit. There were no significant effects of amendments/herbicides on strawberry yield or average individual fruit weight in Iteration 2.

\section{Discussion}

Weed abundance and treatment effects differed between iterations. Strawberry plots 
were rated weedier and total weeding time was greater in Iteration 2 than in Iteration 1 regardless of treatment. Total weeding time for strawberry treated with herbicide or highglucosinolate MSM was $2 \%$ to $8 \%$ less than for nontreated strawberries in Iteration 1, whereas reductions ranged from $12 \%$ to $29 \%$ in Iteration 2 . These reductions in weeding time were not statistically significant in Iteration 1 but were in Iteration 2 despite total weeding time for these treatments taking 100 to $300 \mathrm{~h} \cdot \mathrm{ha}^{-1} /$ person longer in Iteration 2.

Plots treated with herbicide, organic amendment, or flame took up to 10 times longer to weed in September than in any of the preceding months of Iteration 1, indicating that there was appreciable weed seed germination or regrowth in the fall of the first year. The pattern was apparent, but less abrupt, in Iteration 2 with a doubling of weeding time occurring in August followed by another doubling of weeding time in September. A contributing factor to this pattern may have been that strawberry growth was sufficient to hinder weeding operations at about this time and care had to be taken to prevent inadvertent damage to crop plants. In either case, most herbicide/ amendment treatments did not differ in weeding times compared with nontreated control plots at that time in either iteration. Pendimethalin, either alone or mixed with oxyfluorfen, however, was still reducing weeding time in September, showing that it had the most persistence under the conditions of this experiment. Flaming at transplanting, too, caused effects that lasted beyond the initial application. Although there were exceptions in both iterations, flaming strawberry PRETR or POSTR typically lowered monthly and total weeding times compared with rototilling.

Flaming was more effective on broadleaf weeds than on grasses regardless of the timing of the flaming operation consistent with previous observations (Anderson, 1977; Cramer et al., 1991). It appears from these data that POSTR flaming is at least as effective for broadleaf weed control as PRETR and did not reduce strawberry growth or yield. There was also no apparent benefit from flaming twice compared with flaming once. Flaming at the time of transplanting reduced total weeding time $\approx 7 \%$ in Iteration 1 and $\approx 10 \%$ in Iteration 2 . It should be noted, however, that strawberry plants in this trial were hand-transplanted, so only minimal soil disturbance occurred. Mechanical transplanters open a continuous furrow and, if used after weed control treatments, are generally thought to increase weed emergence, so their use would perhaps offset weed density reductions gained from the initial flaming.

Compared with rototilling, all flame treatments increased individual fruit weight and berry yield in Iteration 1; this trend toward higher yields in strawberry flamed at transplanting was also apparent in Iteration 2. Given the greater vegetative and reproductive strawberry productivity after flaming, it is tempting to suspect the activity of some other factor (e.g., less settling of soil in flamed plots resulting in less strawberry crown exposure) was indirectly enhanced by flaming.

Like flaming, CGM was more active on broadleaf weeds than on grasses, but unlike flaming, CGM did not generally reduce total weeding time. In fact, weeding time increased by $121 \mathrm{~h} \cdot \mathrm{ha}^{-1} /$ person in plots treated with CGM at $487 \mathrm{~kg} \cdot \mathrm{ha}^{-1}$ in Iteration 1 . Highglucosinolate MSM was effective on both grasses and broadleaf weeds, particularly in Iteration 2 in which total weeding time was reduced by $16 \%$. Low-glucosinolate MSM also reduced broadleaf weed density in June of Year 1 in both iterations, although populations were similar to those in non-treated control plots by September. Strawberry vegetative growth generally increased after treatment with CGM or low-glucosinolate MSM and was particularly evident in Iteration 2 , in which nine of 12 parameters were positively affected by these organic amendments. Still, improved vegetative growth resulting from these treatments did not appear to impact berry yield or individual fruit weight, because only CGM at $974 \mathrm{~kg} \cdot \mathrm{ha}^{-1}$ in Iteration 1 significantly increased berry yield and in that case did not affect strawberry growth measurements. From these data, it appears that CGM and low-glucosinolate MSM may aid in vegetative growth of strawberry but have little impact on weeding time or berry yield parameters under PNW conditions. WG was generally not an effective amendment, causing no difference in weed density and increasing weeding time in Iteration 2 . WG did not affect strawberry growth parameters in either iteration but did improve berry yield in Iteration 1.

Conversely, high-glucosinolate MSM at $644 \mathrm{~kg} \cdot \mathrm{ha}^{-1}$ numerically reduced strawberry leaf area, berry yield, and individual fruit weight in Iteration 1 and yield in Iteration 2. Effects of this treatment were comparable to the effects recorded from herbicide applications in this experiment, except highglucosinolate MSM generally caused less vegetative injury to strawberry in Iteration 2. Of the organic amendments tested here, then, it appears that high-glucosinolate MSM was the best product for weed control, but lower rates should be evaluated to reduce potential for strawberry injury.

The 3-fold difference in precipitation received in the first 3 or $4 \mathrm{~d}$ after initial application of organic amendments during the two iterations (a 7-fold difference in the first month) did not greatly affect the relative effectiveness of these products for weed control. As evidenced by weed ratings and weeding times, more weeds were found in the wetter spring of Iteration 2 than in the drier spring of Iteration 1 regardless of treatment. The relative ability of CGM to control grasses was poorer during the dry spring, however, although highglucosinolate MSM provided relatively greater grass and broadleaf control during the wet spring. Strawberry plants produced more leaf area, runners, and daughter plants when treated with CGM or low-glucosinolate MSM in the wetter year, although all plots received equivalent levels of $\mathrm{N}$. This may be a result of higher $\mathrm{N}$ levels in foliage of CGM-treated strawberry, a response previously noted by Nonnecke and Christians (2002). These organic amendments may have provided more $\mathrm{N}$ to young strawberry plants at a time when top-dressed nitrate could have leached from the rooting zone as a result of greater summer precipitation in Iteration 2, resulting in more available $\mathrm{N}$ later in the summer. If accurate, it is not clear why treatment with high-glucosinolate MSM or WG did not similarly enhance vegetative growth of strawberry.

In conclusion, results from these trials indicate that CGM and WG applied at transplanting did not provide weed control benefit in the maritime PNW. Strawberry vegetative growth was enhanced by CGM during establishment, however, and CGM applied at $974 \mathrm{~kg} \cdot \mathrm{ha}^{-1}$ or WG at $700 \mathrm{~kg} \cdot \mathrm{ha}^{-1}$ improved berry yield in one of two iterations. Lowglucosinolate MSM at $644 \mathrm{~kg} \cdot \mathrm{ha}^{-1}$ aided in control of broadleaf weeds, whereas highglucosinolate MSM at the same rate aided in the control of both broadleaf and grass weeds, particularly if the product was adequately incorporated by rainfall. High-glucosinolate MSM reduced weeding time but also decreased berry yield and individual fruit weight in one of the two iterations. Flaming immediately before or after strawberry transplanting reduced weeding time more often than not and improved vegetative strawberry growth, berry yield, and individual fruit weight in one iteration of two. These data, however, did not indicate a combined effect of flaming and organic amendments.

\section{Literature Cited}

Albay, F. and Ö. Boz. 2003. Investigation on the efficacy of olive processing waste and corn gluten meal for weed control in strawberry. Proc. European Weed Res. Soc. Mediterranean Symposium. p. 27-28.

Anderson, W.P. 1977. Methods of weed control, burning, p. 67-70. In: Weed science principles. West Publishing Company, St. Paul, MN.

Balsari, P., R. Berruto, and A. Ferrero. 1994. Flame weed control in lettuce crop. Acta Hort. 372: 213-222.

Bañuelos, G.S. and B.D. Hanson. 2010. Use of selenium-enriched mustard and canola seed meals as potential bioherbicides and green fertilizer in strawberry production. HortScience 45:1567-1572.

Berglund, R., B. Svensson, and U. Gertsson. 2006. Impact of plastic mulch and poultry manure on plant establishment in organic strawberry production. J. Plant Nutr. 29:103-112.

Borek, V., L.R. Elberson, J.P. McCaffrey, and M.J. Morra. 1997. Toxicity of rapeseed meal and methyl isothiocyanate to larvae of the black vine weevil (Coleoptera: Curculionidae). J. Econ. Entomol. 90:109-112.

Borek, V. and M.J. Morra. 2005. Ionic thiocyanate $\left(\mathrm{SCN}^{-}\right)$production from 4-hydroxylbenzy glucosinolate contained in Sinapis alba seed meal. J. Agr. Food Chem. 47:3837-3842.

Boydston, R.A., T. Anderson, and S.F. Vaughn. 2008. Mustard (Sinapis alba) seed meal suppresses weeds in container-grown ornamentals. HortScience 43:800-803. 
Boydston, R.A., M.J. Morra, V. Borek, L. Clayton, and S.F. Vaughn. 2011. Onion and weed response to mustard (Sinapis alba) seed meal. Weed Sci. 59:546-552.

Brown, P.C., M.J. Morra, J.P. McCaffrey, D.L. Auld, and L. Williams, III. 1991. Allelochemicals produced during glucosinolate degradation in soil. J. Chem. Ecol. 17:2021-2034.

Caldwell, B. and C.L. Mohler. 2001. Stale seedbed practices for vegetable production. HortScience 36:703-705.

Christians, N.E. 1993. The use of corn gluten meal as a natural preemergence weed control in turf. Intl. Turfgrass Soc. Res. J. 7:284-290.

Cramer, C., G. Bowman, M. Brusko, K. Cicero, B. Hofstetter, and C. Shirley. 1991. Direct seed and flame weed, p. 74-76. In: Controlling weeds with fewer chemicals. Rodale Institute, Emmaus, PA.

Daugaard, H. 1999. Cultural methods for controlling Botrytis cinerea Pers. in strawberry. Biological Agriculture \& Horticulture Intl. J. 16: 351-361.

Dilley, C.A., G.R. Nonnecke, and N.E. Christians. 2002. Corn-based extracts to manage weeds and provide nitrogen in matted-row strawberry culture. HortScience 37:1053-1056.

Gengotti, S. and C. Lucchi. 2000. Useful advice for growing strawberries organically in EmiliaRomagna. Rivista di Frutticoltura e di Ortofloricoltura 62:60-62.

Gough, R.E. and R. Carlstrom. 1999. Wheat gluten meal inhibits germination and growth of broadleaf and grassy weeds. HortScience 34:269-270.

Johnson, M.S. and S.A. Fennimore. 2005. Weed and crop response to colored plastic mulches in strawberry production. HortScience 40:13711375.

Kelly, M.J., M.P. Pritts, and R.R. Bellinder. 2007. Evaluation of new cultivation tools to reduce labor requirements in matted-row strawberry culture. HortTechnology 17:87-94.

Mazzola, M., D.M. Granatstein, D.C. Elfving, and K. Mullinix. 2001. Suppression of specific apple root pathogens by Brassica napus seed meal amendment regardless of glucosinolate content. Phytopathology 91:673-679.

Meshcheryakova, I.V. 1986. After the strawberry harvest. Zashchita Rasteniǐ 7:56-57.

Nonnecke, G.R. and N.E. Christians. 1993. Evaluation of corn gluten meal as a natural, weed control product in strawberry. Acta Hort. 348:315-320.

Nonnecke, G.R. and N.E. Christians. 1997. Strawberry production using corn gluten meal as a natural nitrogen source and weed control product. Acta Hort. 439:725-730.

Nonnecke, G.R. and N.E. Christians. 2002. Effects of source, rate, and particle size of corn gluten meal on weed and strawberry growth and development. Proc. $5^{\text {th }}$ North American Strawberry Conf. p. 124-128.

Pritts, M.P. and M.J. Kelly. 2001. Early season weed competition reduces yield of newly planted matted row strawberries. HortScience 36:729-731.
Pritts, M.P. and M.J. Kelly. 2004. Weed competition in a manure matted row strawberry planting. HortScience 39:1050-1052.

Qing, Y., T. Rong, M. Chiba, and J. Potter. 2007. J. Food Agr. Environ. 5:374-379.

Rice, A.R., J.L. Johnson-Maynard, D.C. Thill, and M.J. Morra. 2007. Vegetable crop emergence and weed control following amendment with different Brassicaceae seed meals. Renewable Agr. and Food Systems 22:204-212.

Smolinska, U., G.R. Knudson, M.J. Morra, and V. Borek. 1997. Inhibition of Aphanomyces euteiches f. sp. pisi. by volatiles produced by hydrolysis of Brassica napus seed meal. Plant Dis. 81:288-292.

Stopes, C. and S. Millington. 1991. Weed control in organic farming systems. Brighton Crop Protection Conf. Weeds., Brit. Crop Protection Council, Farnham, UK. p. 185-192.

Titov, D.A. 1986. Mites on strawberry. Zashchita Rasteniı̌ 9:48.

Vaughn, S.F. and M.A. Berhow. 2005. Glucosinolate hydrolysis products from various plant sources: PH effects, isolation and purification. Ind. Crops Prod. 21:193-202.

Vaughn, S.F., D.E. Palmquist, S.M. Duval, and M.A. Berhow. 2006. Herbicidal activity of glucosinolate-containing seedmeals. Weed Sci. 54:743-748

Wookey, C.B. 1985. Weed control practice on an organic farm. Brit. Crop Protection Conf. Weeds. Brit. Crop Protection Council, Croydon, UK. p. 577-582. 